Article

\title{
Twenty Years after the Nakhodka Oil Spill Accident in the Sea of Japan, How Has Contamination Changed?
}

\author{
Kazue Tazaki ${ }^{1, *}$, Atsuko Fukuyama ${ }^{2}$, Fumie Tazaki ${ }^{3}$, Yoshiaki Shintaku ${ }^{4}$, Keiichi Nakamura ${ }^{5}$, \\ Teruaki Takehara ${ }^{6}$, Yoshihiro Katsura ${ }^{7}$ and Keisuke Shimada ${ }^{7}$ \\ 1 Kahokugata Lake Institute, Kanazawa University, Na 9-9, Kitachujo, Tsubata, Kahokugun, \\ Ishikawa 929-0342, Japan \\ 2 Headquarters for Innovative Society Academia Cooperation, University of Fukui, 3-9-1 Bunkyo, \\ Fukui 910-8507, Japan; atsukof@u-fukui.ac.jp \\ 3 Department of Occupational Therapy, Osaka Kawasaki Rehabilitation University, 158 Mizuma, Kaizuka, \\ Osaka Prefecture 597-0104, Japan; taz23a@sky.plala.or.jp \\ 4 NPO Nozominosato, 5567-1 Fukushima, Kiso, Nagano 397-0001, Japan; nozominosato@circus.ocn.ne.jp \\ 5 Yamato Environmental Analysis Co., Ltd., 273 Santanda, Kawakita, Nomi-gun, Ishikawa 923-1253, Japan; \\ nakamura@yamatokankyo.co.jp \\ 6 Medical Research Institute, Kanazawa Medical University, 1-1 Daigaku, Uchinada, Kahokugun, \\ Ishikawa 929-0342, Japan; take@kanazawa-med.ac.jp \\ 7 Ishikawa Museum of Natural History, Ri 441 Choshi-machi, Kanazawa, Ishikawa 920-1147, Japan; \\ katsura@n-muse-ishikawa.or.jp (Y.K.); kshimada@n-muse-ishikawa.or.jp (K.S.) \\ * Correspondence: kazuet@cure.ocn.ne.jp; Tel./Fax: +81-76-223-6977
}

Received: 2 February 2018; Accepted: 17 April 2018; Published: 24 April 2018

\begin{abstract}
The Nakhodka, a Russian tanker loaded with 19,000 kL of C-type heavy oil, was broken up into sections and submerged off Oki Island, Shimane Prefecture, Japan on 2 January 1997. The bow, after drifting for four days, was wrecked off Anto, Sakai City (Mikuni), Fukui Prefecture, threatening the environment throughout the various shores of Ishikawa Prefecture. The accident, caused by a heavy oil spill of $6200 \mathrm{~kL}$, created serious environmental problems along the shores of Hokuriku District. We report the characterization of C-type heavy oil 20 years after the accident at the Atake seashore, Wajima City, Ishikawa Prefecture, in the Sea of Japan, based on observations in the field on 18 January 2017. We studied the microstructure, mineralogy, chemical composition, and radioactivity associated with microorganisms in the soils, and buried fishing nets and ropes that were contaminated with C-type heavy oil from this spill. The analyses used a combination of micro techniques, analytical data based on a CHN analyzer, X-ray powder diffraction (XRD), and two kinds of scanning electron microscopy equipped with energy dispersive spectroscopy (SEM-EDS). Hydrocarbon-degrading bacteria, paraffin wax, cristobalite, graphite, calcite, halite, and biotite from the Nakhodka oil spill were recognized on the surface of ropes and in the soil of the polluted seashores after 20 years. The chemical compositions indicated that high concentrations of $\mathrm{C}, \mathrm{O}, \mathrm{Na}, \mathrm{Al}, \mathrm{Si}, \mathrm{P}, \mathrm{S}$, $\mathrm{Ca}, \mathrm{Fe}, \mathrm{Cl}, \mathrm{Sr}$, and $\mathrm{Pb}$ were predominantly indigenous to the Nakhodka oil spill. In the XRD analysis of the oil-contaminated soils on the rope at the Atake seashore indicated paraffin wax, graphite, sulfate, calcite and halite refractions with clay minerals, after 20 years. To date, no report has described the results of electron microscopy observations, such as Micrococcus bacillus and filamentous fungi, found in oil-contaminated soils after 20 years. In this research, such observations are introduced as "bioremediation" by hydrocarbon-degrading bacteria, graphite, and paraffin wax. On 18 January 2017, the reflection of graphite, paraffin wax, sulfur, calcite, and halite with clay minerals confirmed the occurrence of bioremediation. Many kinds of hydrocarbon-degrading microorganisms-such as filamentous fungi-were found in oil-contaminated soils after 20 years. We have used SEM-EDS to show semi-permanent bioremediation and biomineralization processes after 20 years.
\end{abstract}


Keywords: 20 years after the Nakhodka oil spill accident; Atake seashore in Wajima; bioremediation; biomineralization; $\mathrm{CHN}$; XRD; SEM-EDS; graphite; paraffin wax; sulfur; calcite; halite

\section{Introduction}

\subsection{The Heavy Oil Spill Accident in 1997}

The Nakhodka, a Russian tanker loaded with 19,000 kL of C-type heavy oil, was divided into sections and submerged off the Oki Islands, Shimane Prefecture, Japan on 2 January 1997. The bow, after drifting for four days, was wrecked off Anto, Sakai City (Mikuni), Fukui Prefecture, threatening various seashores throughout Ishikawa Prefecture, geographically, as well. The serious heavy oil spill from the wrecked bow in Ishikawa is shown in Figure 1a. This incident-resulting in a heavy oil spill of $6200 \mathrm{~kL}$-yielded serious environmental problems throughout the shores of Hokuriku District $[1,2]$. The heavy oil and the waste was collected in drum-cans and carried to the waste site and buried there (Figure 1a,b). Rocks at Katano seashore, Kaga City, Ishikawa were covered with heavy oil everywhere (Figure 1c). The collected heavy oil was equivalent to approximately 110,000 drum-cans containing 22,305 kL. We carried out on-site investigations immediately, and measured the level of pollution, studied the C-type heavy oil ingredients and its toxicity, developed methods of removing heavy oil, and also carried out various studies, such as the effects on inter-tidal organisms and micro-bioremediation. Approximately 100,000 volunteers participated [1,2]. The waste, mixed with heavy oil, washed ashore on the coast and was buried in a sandy beach and in the soil before we were able to collect it all (Figure 1b). The oil on the concrete blocks by the coast was removed with a high temperature, high pressure nozzle for aesthetic reasons.

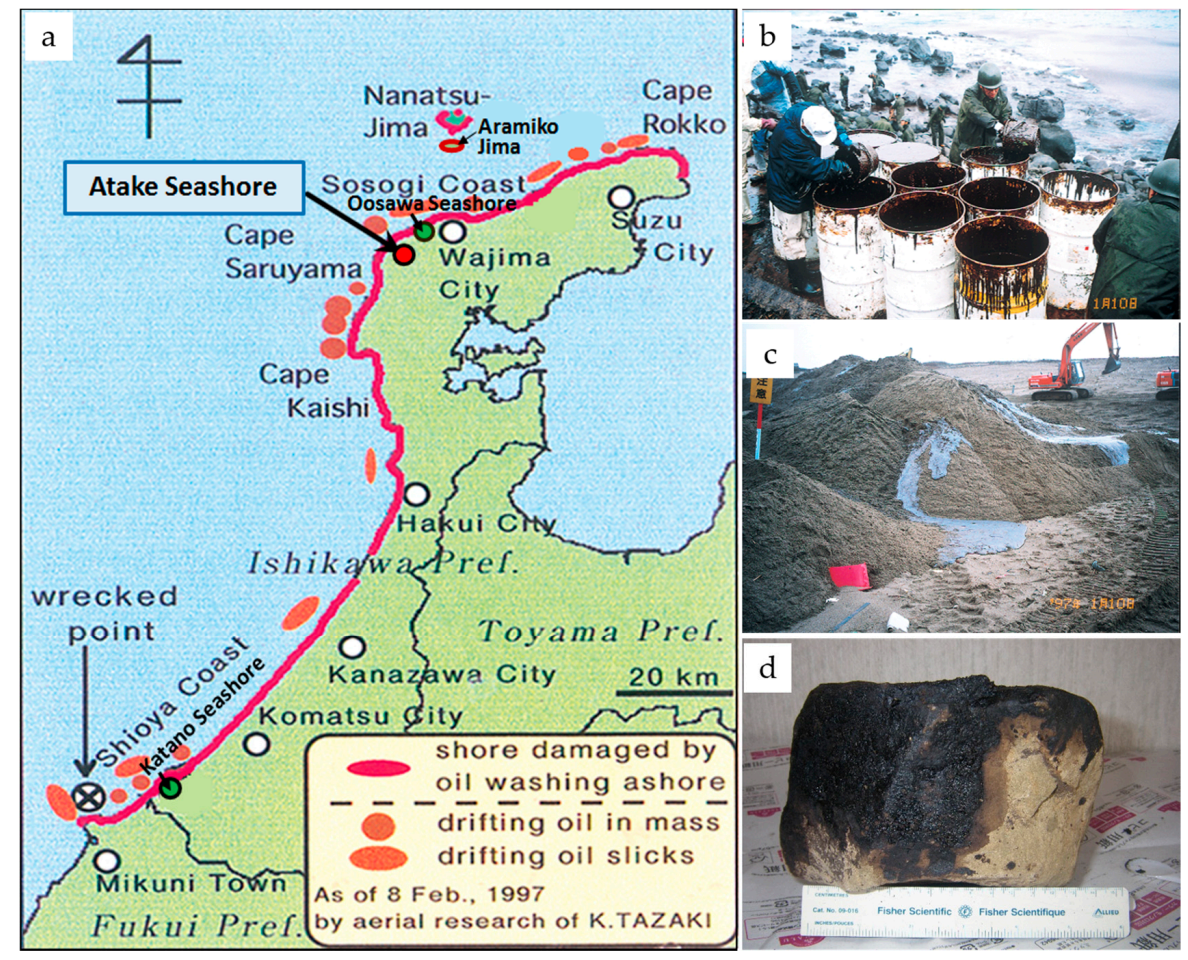

Figure 1. Distribution map of heavy oil from the Nakhodka oil spill-polluted seashores in the Sea of Japan on 8 February 1997 by the aerial research of Tazaki (1997) [1] (a); collected heavy oil in drum-cans at seashores in Sakai (Mikuni), Fukui, Japan in 1997 (b); collection of heavy oil on the sandy beach in 1997 (c); and a rock sample covered by heavy oil changed to paraffin wax after nine years in 2005 (d). 
A very small amount of heavy oil continued to leak out of the ship's hull, which had sunk off Shimane afterwards. Under the influence of periodic winter winds, the leaked oil was repeatedly blown ashore on the coast of Hokuriku. At the time of the accident, the Nakhodka had sunk in deep waters $2400 \mathrm{~m}$ off the Oki Islands with more than 19,000 kL of heavy oil in the ship's hull. Even though an oil slick was not confirmed on the sea for several years, the heavy oil might have leaked from the hull section of the Nakhodka [1-6].

At the time of the accident, a large quantity of heavy oil was washed ashore from Anto to the shoreline of Noto Peninsula (located to approximately $146 \mathrm{~km}$ from Anto to the north) in the Sea of Japan (Figure 1a). Much heavy oil was washed ashore-more than the heavy oil washed ashore from Anto. On some more distant shorelines where news was not reported, collection work of the heavy oil was carried out at that time by local people. In December 2006, we published an article entitled "What did we learn from the Nakhodka oil spill accident in ten years?" and announced our findings at the meeting of the international society $[7,8]$.

\subsection{Twenty Years after (2017) the Heavy Oil Accident in 1997 (Atake Seashore in Ishikawa)}

The authors got an opportunity to accompany a group of reporters for Kanazawa TV on an investigation of the Atake seashore in Wajima City, Ishikawa Prefecture. At the time of the spill, more heavy oil was washed ashore on this coast than that in Anto. We report the present conditions 20 years after the accident because we had the opportunity of collecting these samples and analyzing them. Since the damage from the heavy oil still impacts the Atake seashore, we deemed it necessary to continue to investigate the natural purification methods for the resolution of the heavy oil by microorganisms. We report the result of our observations and analyses from the standpoints of physics, chemistry, mineralogy, and microbiology.

\section{Materials and Methods}

\subsection{Exploring the Nakhodka Oil Spill Accident Field and Investigated Specimens}

The author (Kazue Tazaki) went to the Atake seashore in Wajima City in 2017 to collect the heavy oil samples for these analyses and observations.

\subsection{Fishing Net and Rope with Heavy Oil}

On 18 January 2017, we investigated the field site 20 years after the Nakhodka oil spill accident on the Atake seashore (Figure 1a). The seawater, the rocks, and the gravel were purified on the Atake seashore, and lumps of heavy oil and traces were not confirmed. However, we obtained information about the flotsam that we had not been able to dispose of from the local people. Therefore, after searching in the neighborhood, soil, fishing nets, and ropes with an oil smell were found buried in the sand (Figure 2a-e). These were confirmed from their color, smell, and stickiness to be flotsam from the Nakhodka oil spill accident. We kept a picture of this beach, taken on 21 November 2001 (Figure 2f) [1]. We collected samples, including a fishing net and a rope covered in oil, buried in the sand (Figure 2a-c). First, we measured the radiation of the rope (Figure 2c). Next, the rope was washed with warm water to separate the rope, the oils, and the soils (Figure $2 \mathrm{~d}, \mathrm{e}$ ). The soils and rope were dark and smelled of heavy oil because the fishing nets and rope had become saturated with the heavy oil. 

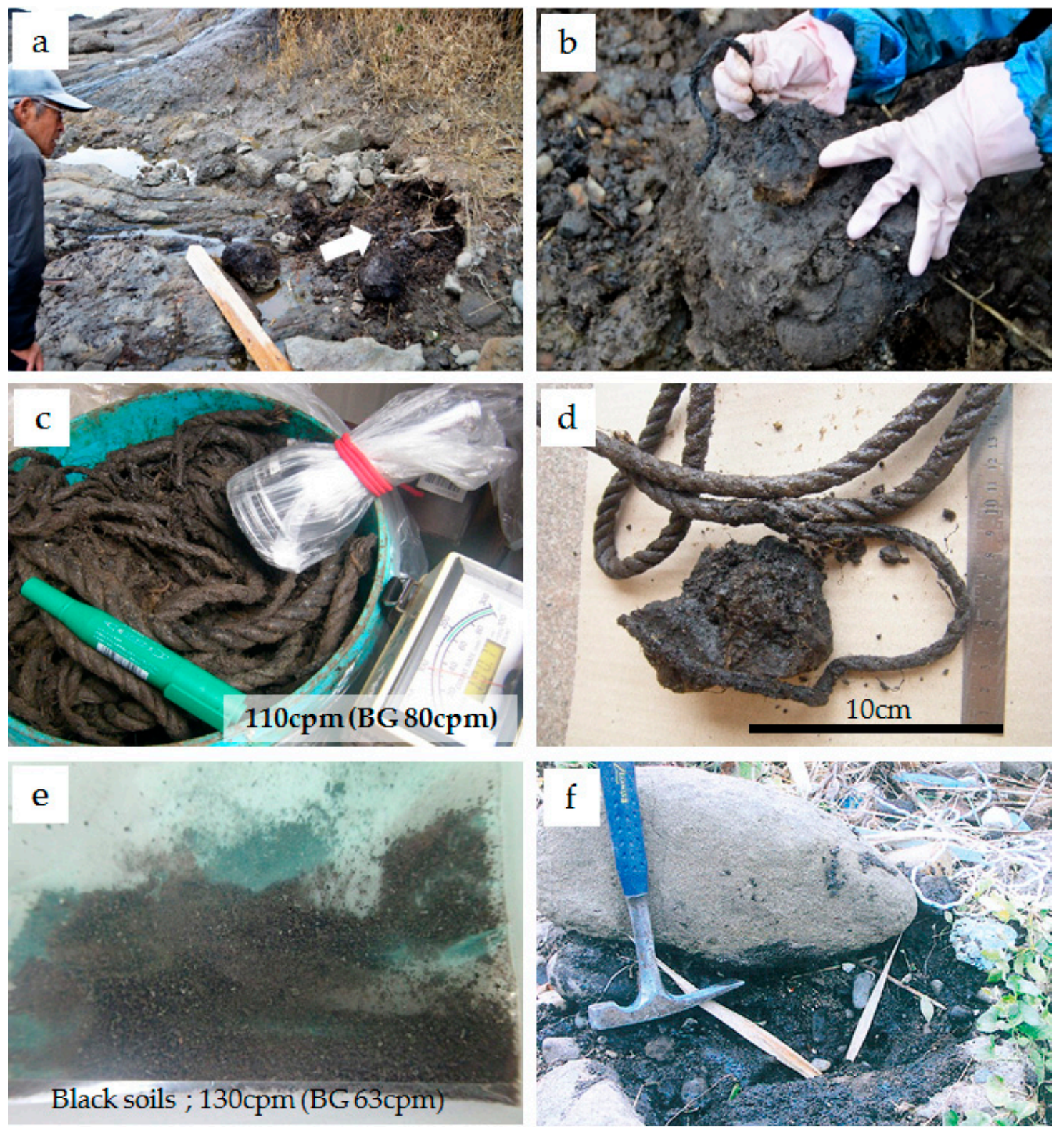

Figure 2. Collected heavy oil with rope and fishing rope and nets on the Atake seashore, Wajima, Ishikawa, Japan in 2017 (a-d); detected radiation of $110 \mathrm{cpm}$ (BG $80 \mathrm{cpm}$ ) (c); black soils also detected radiation of $130 \mathrm{cpm}$ (BG $63 \mathrm{cpm}$ ) on 2 May 2017 (e); the black soils contained C (11.6\%), H (1.8\%), $\mathrm{N}(0.1 \%)$, and were reduced in weight by heating $(15.5 \%)$, as determined by CHN analysis (e); and follow-up field investigations at the Atake seashore. Heavy oil still remained under the rock (21 November 2001) (f) [1].

\subsection{X-ray Powder Diffraction (XRD)}

The contaminated soils with oil were divided into two parts-the rough grain portion $(\mathrm{mm}$ size) and the fine grain portion ( $\mu \mathrm{m}$ size) - and the minerals were identified using an X-ray analyzer (Figure 3). An XRD (Rinto 2200, Rigaku, Tokyo, Japan; Cu-K $\alpha$ radiation, 40 kV, $30 \mathrm{~mA}$, scan speed of $2^{\circ} / \mathrm{min}$ ) was used for identification of minerals in the oil-contaminated soils. The powder samples (bulk, $<2 \mu \mathrm{m}$, and suspension) were used for X-ray powder diffraction analyses. 


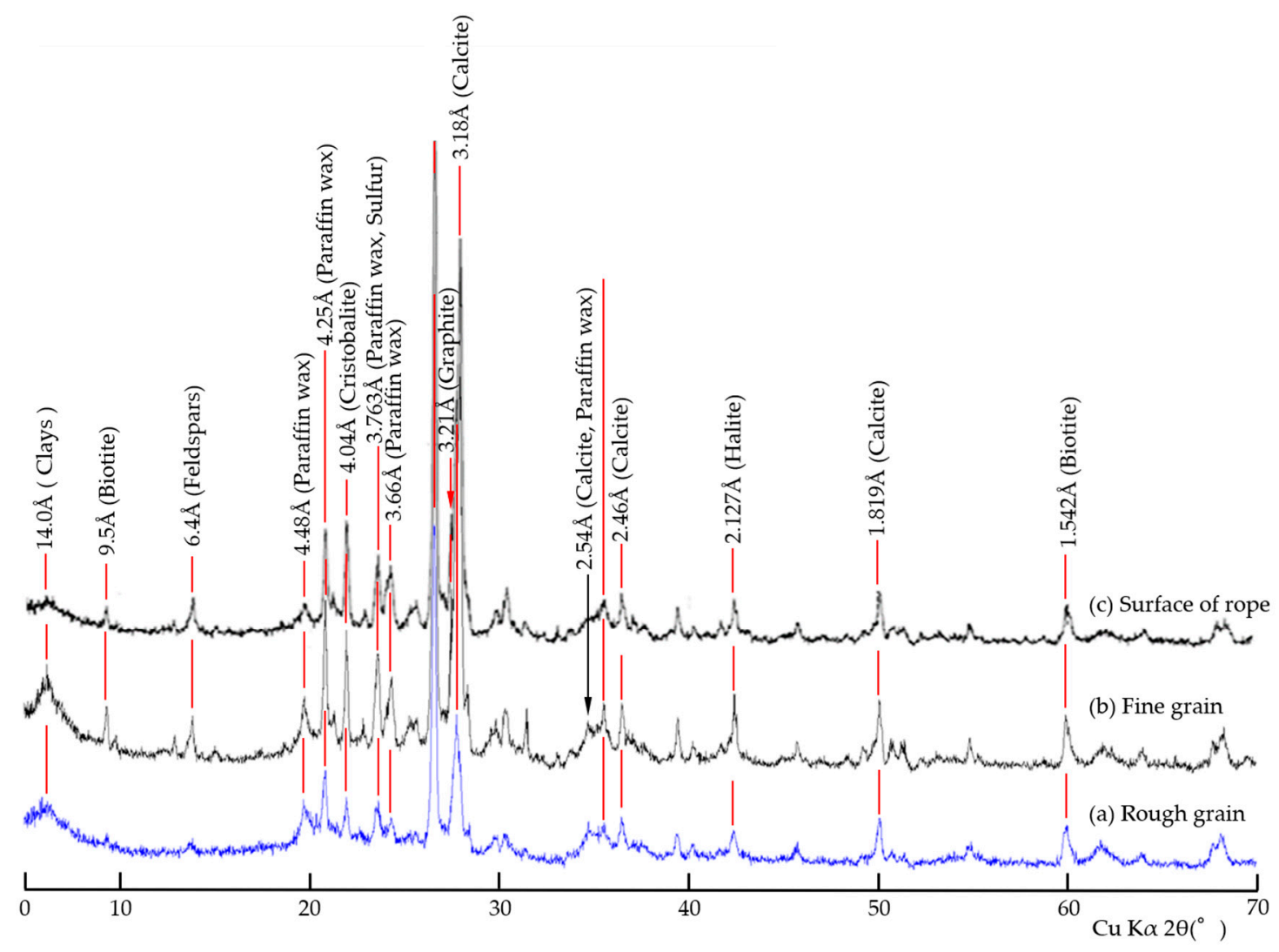

Figure 3. XRD analyses of the contaminated soils with oil divided into the rough grain portion (a), the fine grain portion (b), and the oily surface of the rope (c) at the Atake seashore, indicated paraffin wax, graphite, sulfur, calcite, and halite refractions associated with clay minerals in the oily soils after 20 years.

\subsection{Radiation Dose Measurement and $\mathrm{H}_{2} \mathrm{O}_{2}$ Reaction}

The organic materials composed of $\mathrm{C}, \mathrm{H}$, and $\mathrm{N}$ in the oil-covered fishing nets and rope were identified using a CHN instrument. The radiation was measured using a GM survey meter TGS-136 of Hitachi-Aloka Medical, Tokyo, Japan (measurements in cpm) (Figure 2c,e). The measuring instrument is a survey meter for $\beta(\gamma)$ that can display both the calculation rate and the multiplication calculation digitally. In addition, $1000 \mathrm{cpm}$ is equivalent to $1.52 \mu \mathrm{Sv} / \mathrm{h}$, with an error of $2-3 \%$.

The presence of organic matter, enzymes, and the microbes were confirmed in all samples by $3.5 \%$ of hydrogen peroxide before analysis. Many organisms are formed to decompose hydrogen peroxide $\left(\mathrm{H}_{2} \mathrm{O}_{2}\right)$ enzymatically [1,2]. Enzymes are globular proteins, responsible for most of the chemical activities of living organisms. They act as catalysts-substances that speed up chemical reactions without being destroyed or altered during the process. $\mathrm{H}_{2} \mathrm{O}_{2}$ is toxic to most living organisms. However, many organisms are capable of enzymatically destroying the $\mathrm{H}_{2} \mathrm{O}_{2}$ before it can do much damage.

\subsection{Scanning Electron Microscopy (SEM) Equipped with Energy Dispersive Spectroscopy (EDS)}

We performed observation and analysis of the oil-contaminated soils and fishing net and rope with acceleration voltages of $10 \mathrm{kV}$ and $20 \mathrm{kV}$, a low vacuum mode using SEM-EDS 6010PLUS/LA scanning electron microscope (JEOL Ltd., Tokyo, Japan), and an energy analysis of variance device. The samples had no coating for the confirmation of the presence of $\mathrm{C}$ and $\mathrm{O}$ with heavy elements. 


\subsection{SEM Equipped with EDS}

We performed observations and analysis of microorganisms in the rope and oil-covered soil using an energy analysis of variance device with an analysis area $10 \mathrm{~mm} \times 10 \mathrm{~mm}$, an analysis time of $1000 \mathrm{~s}$, an acceleration voltage of $15 \mathrm{kV}$, a Pt coating, and $70 \mu \mathrm{A}-80 \mu \mathrm{A}$ (Horiba EMAX, Kyoto Prefecture, Japan) attached to a scanning electron microscope (S-3400N. Hitachi, Ibaraki Prefecture, Japan). The samples were set on carbon double-stick tape and coated with a Pt coating, and we then acquired an element concentration distribution map (Figure 7).

\subsection{The Identification of Bacteria}

A careful bioremediation research of the Nakhodka oil spill along seashores ionn the Sea of Japan has been performed since 1997. The experimental procedure followed that previously described in 1997 [1,2]. After a five-year bioremediation process, the isolation of indigenous bacterial strains was conducted in three coastal areas (Katano seashore of Fukui Prefecture, and Atake and Ozawa seashores of Ishikawa Prefecture), and the Nakhodka Russian oil tanker. Bacteria capable of degrading hydrocarbons were isolated directly from samples of heavy oil, sand, and seawater contaminated by the Nakhodka oil spill by selective enrichment using Bushnell Hass Mineral Salts medium (BHMS) modified with $2 \% \mathrm{NaCl}$ and supplied with heavy oil 1\% $(v / v)$ from the Nakhodka oil spill as the sole added carbon and energy source. Bacterial strains capable of growing on heavy oil were isolated from the above four locations by using enrichment and isolation techniques. Of the 39 bacterial strains tested, only seven bacterial strains could grow very well on heavy oil (unpublished data).

\section{Results}

\subsection{Radiation Dose Measurement and $\mathrm{H}_{2} \mathrm{O}_{2}$ Reaction}

The radiation dose after having air-dried the rope for three months was a high background of $110 \mathrm{cpm}$ for BG $80 \mathrm{cpm}$ (Figure 2c) and the black soils were even higher, at $130 \mathrm{cpm}$ for BG $63 \mathrm{cpm}$ (Figure 2e). The surface of the rope reacted with the $\mathrm{H}_{2} \mathrm{O}_{2}$ solution, showing many white bubbles, indicating the existence of organic matter and microorganisms in and around the rope. The soil around the rope was divided into the rough grain portion and the fine grain portion by a water sieve, and the fine grain soil reacted strongly with the $\mathrm{H}_{2} \mathrm{O}_{2}$ solution. The $\mathrm{pH}$ of the suspension was measured at $\mathrm{pH} 6$.

\subsection{Mineral Profiling}

In 1997 the X-ray powder diffraction patterns of the Nakhodka heavy oil, only a reflection of halite, thought to be of seawater origin, was indicated conspicuously at 2.1 A. Nine years after the Nakhodka oil spill accident (2005), the thin oil crust on the surface of the rock at Anto was easily exfoliated (Figures $1 \mathrm{~d}$ and $4 \mathrm{~h}-\mathrm{i}$ ). On the XRD patterns of both the surface and the reverse sides, a reflection of paraffin wax of 1000 cps strength was indicated at $4.2 \AA, 3.7 \AA$, and $2.5 \AA$, and the reflection of halite was not indicated. The crystallinity of the paraffin was higher on the surface side. However, the reflection patterns of paraffin $(4.12 \AA)$, graphite $(3.34 \AA)$, and calcite $(3.02 \AA)$ of low crystallinity were indicated in the X-ray powder diffraction analysis of dried heavy oil in the laboratory in $2005[8,9]$. The ridges formed in certain crystallographic directions on the crystals of normal alkanes are related to the shearing which occurs when molecular chains undergo tilting.

In the XRD analysis of the oil-contaminated soils on the rope that was unearthed from the sand at the Atake seashore on 18 January 2017, the peaks of the clay minerals at $14 \AA$, biotite $(9.5 \AA)$, feldspars (6.4 $\AA$ ), cristobalite $(4.04 \AA)$, halite $(2.13 \AA)$, and paraffin wax $(4.25 \AA, 3.76 \AA, 2.52 \AA)$ indicated strong reflections of about 1000 cps, and reflections of graphite ( $3.34 \AA$ ) and calcite $(3.18 \AA$, $2.46 \AA$ ) were also indicated (Figure 3). In addition, the fine grain showed a stronger reflection than that of the rough grain. Moreover, in the oil on the rope, the reflection of paraffin wax $(4.25 \AA, 3.76 \AA, 2.52 \AA)$, graphite $(3.345 \AA)$, cristobalite $(4.04 \AA)$, calcite $(3.18 \AA)$, and halite $(2.13 \AA$ ) were indicated (Figure $3 c)$. These XRD patterns indicated a greater variety of mineral occurrences in 2017 (Figure 3). 

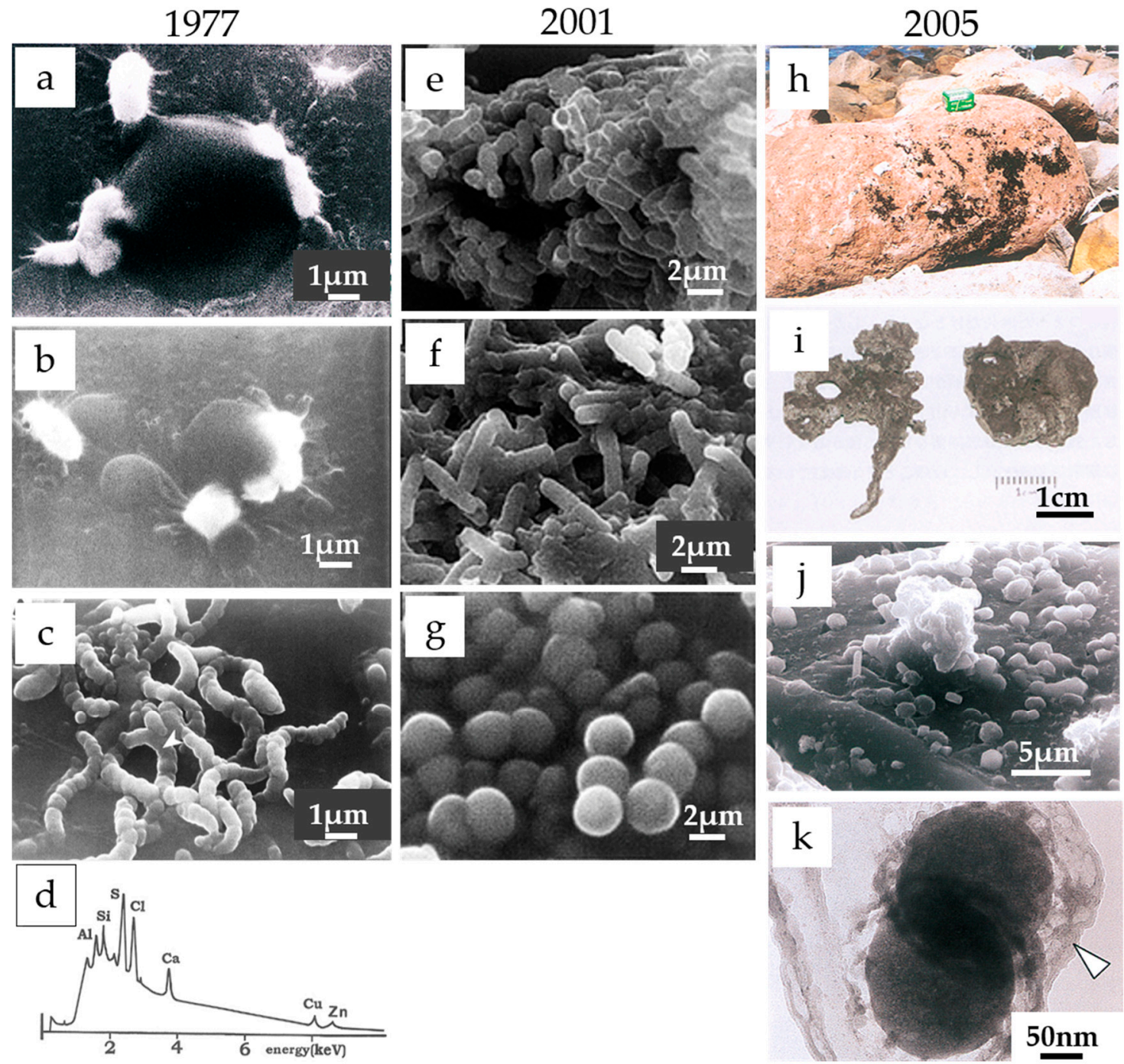

Figure 4. SEM and TEM electron micro-morphologies of bio-remediation bacteria after the Nakhodka heavy oil spill accident [1,2,4-9]. (a,b) The TEM oil samples collected from the Shioya seaside, Kaga, Ishikawa, in March 1997; (c,d) the SEM and XRD oil samples collected from Aramiko Island, Ishikawa, in March 1997; (e) the SEM oil sample drained from the Nakhodka tanker in 2001; (f) the SEM oil sample collected from the Katano seashore, Kaga, Ishikawa, in 2001; (g) the SEM oil sample collected from the Osawa seaside, Ishikawa, in 2001; (h-k) the samples collected from Anto, Sakai (Mikuni), Fukui, in October 2005, showing the adhesion of black oil on the surface of the rock (h); peeled-off black thin films from the surface of the rock (i); the SEM micromorphology of the peeled-off thin films, and the TEM micromorphology of the cocci covering thin films around the cell (an arrow) $(\mathbf{j}, \mathbf{k})$.

\subsection{Elemental Composition by EDS}

The lump of dried oil, the oil on the rope, and the soil divided into rough grain (Figure 5a) and fine grain (Figure $5 b$ ) by a water sieve after washing with boiling water were analyzed at acceleration voltages of $10 \mathrm{kV}$ and $20 \mathrm{kV}$ (EDS system, no coating samples), and compared. The results are shown in Table 1. The dry sample had much $\mathrm{C}$ and $\mathrm{O}$ derived from the oil. The $\mathrm{Al}$ and Si derived from the sand comprised 3-17\%, and no, or almost no, $\mathrm{Cl}$ derived from seawater remained. On the other hand, in the sample which was washed with boiling water, the oil ingredients $(C, S)$ and the seawater ingredient $(\mathrm{Cl})$ decreased, but the oil ingredient $(\mathrm{C})$ remained in both the rough and the fine grain portions. There were many mineral ingredients, such as $\mathrm{Na}, \mathrm{Al}$, and $\mathrm{Si}$, in the rough grain portion. 


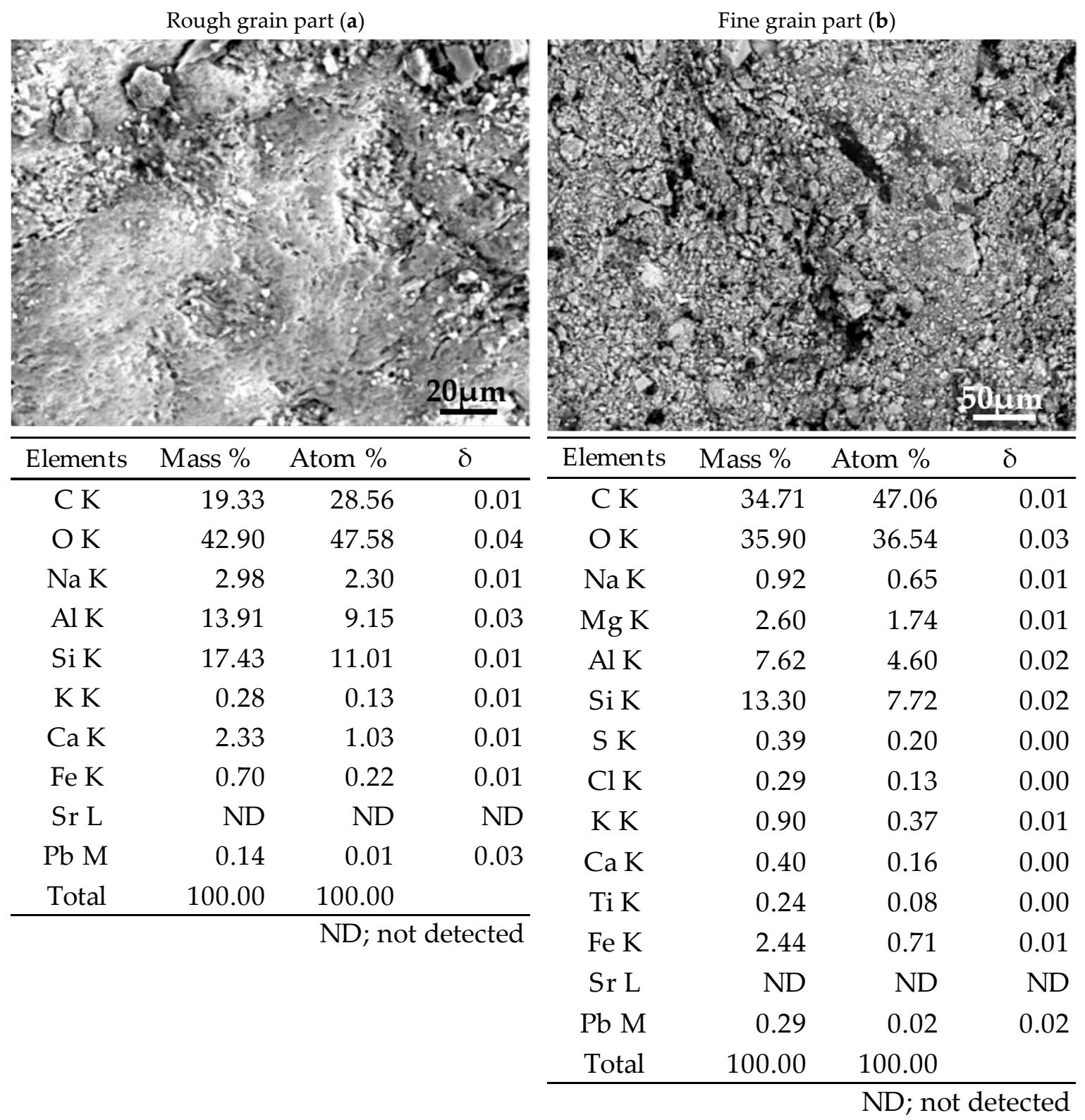

Figure 5. SEM-EDS analyses of the contaminated soils with oil collected at the Atake seashore, divided into the rough grain portion (a) and the fine grain portion (b). The analysis of the samples, which have no coating, detected mainly C, O, Na, Mg, Al, Si, K, Ca, and Fe in May 2017. EDS spectra can be clarified by removing the grid behind the spectra.

Analysis by SEM-EDS (no coating, acceleration voltage $20 \mathrm{kV}$ ) was performed on the rough grain portion in the soils around the oil-covered rope collected at the Atake seashore (Table 1). In the results, $\mathrm{C}(19.33 \%), \mathrm{O}(42.90 \%), \mathrm{Na}(2.98 \%), \mathrm{Al}(13.91 \%), \mathrm{Si}(17.43 \%)$, and $\mathrm{Ca}(2.33 \%)$ were the main components, and a small quantity of $\mathrm{K}, \mathrm{Fe}$, and $\mathrm{Pb}$ were also included. On the other hand, $\mathrm{C}(34.71 \%), \mathrm{O}(35.90 \%)$, $\mathrm{Al}(7.62 \%)$, and $\mathrm{Si}(13.30 \%)$ were the main components in the fine grain portion, and a small amount of $\mathrm{Na}(0.92 \%), \mathrm{Mg}(2.60 \%), \mathrm{Fe}(2.44 \%)$, and a very small amount of $\mathrm{S}, \mathrm{Cl}, \mathrm{K}, \mathrm{Ca}$, $\mathrm{Ti}$, and $\mathrm{Pb}$, were also included (Table 1). The values obtained with an acceleration voltage of $10 \mathrm{kV}$ cannot be directly compared with that for $20 \mathrm{kV}$ because several light elements, including $\mathrm{C}$ and $\mathrm{O}$, are detected. 
Table 1. Scanning electron microscopy and energy dispersive analyses of oil and soils on the rope collected from the Atake seashore, showing an abundance of $\mathrm{C}, \mathrm{O}, \mathrm{Al}, \mathrm{Si}$, and Fe. (SEM-EDS system; no coating samples, acc. vol. $10 \mathrm{kV}$ and $20 \mathrm{kV}$ ).

\begin{tabular}{cccccc}
\hline Elements & $\begin{array}{c}\text { Dried Oil } \\
\text { Mass \% }\end{array}$ & \multicolumn{2}{c}{ Acc. Vol. 10 kV } & \multicolumn{2}{c}{ Acc. Vol. 20 kV } \\
\cline { 3 - 6 } & Mass \% & $\begin{array}{c}\text { Rough Grain } \\
\text { Mass \% }\end{array}$ & $\begin{array}{c}\text { Fine Grain } \\
\text { Mass \% }\end{array}$ & $\begin{array}{c}\text { Rough Grain } \\
\text { Mass \% }\end{array}$ \\
\hline $\mathrm{C}$ & 77.50 & 48.77 & 33.29 & 34.71 & 19.33 \\
$\mathrm{O}$ & 13.15 & 28.80 & 32.20 & 35.90 & 42.90 \\
$\mathrm{Na}$ & 0.45 & 0.75 & 0.72 & 0.92 & 2.98 \\
$\mathrm{Mg}$ & 0.83 & 2.24 & 3.44 & 2.60 & ND \\
$\mathrm{Al}$ & 2.64 & 6.68 & 7.94 & 7.62 & 13.91 \\
$\mathrm{Si}$ & 3.84 & 11.16 & 14.83 & 13.30 & 17.43 \\
$\mathrm{~S}$ & 0.79 & 0.64 & 0.47 & 0.39 & ND \\
$\mathrm{Cl}$ & 0.36 & ND & ND & 0.29 & ND \\
$\mathrm{K}$ & 0.35 & 0.95 & 1.25 & 0.90 & 0.28 \\
$\mathrm{Ca}$ & $\mathrm{ND}$ & ND & ND & 0.40 & 2.33 \\
$\mathrm{Ti}$ & $\mathrm{ND}$ & ND & ND & 0.24 & ND \\
$\mathrm{V}$ & 0.02 & 0.01 & 0.06 & ND & ND \\
$\mathrm{Fe}$ & $\mathrm{ND}$ & ND & 5.78 & 2.44 & 0.7 \\
$\mathrm{~Pb}$ & $\mathrm{ND}$ & ND & ND & 0.29 & 0.14 \\
$\mathrm{Sr}$ & 0.07 & ND & ND & ND & ND \\
$\mathrm{Total}$ & 100.00 & 100.00 & 99.98 & 100.00 & 100.00 \\
\hline
\end{tabular}

ND: not detected; acc.: acceleration voltage.

\subsection{The Elemental Composition of Microbial Cells by EDS}

The section of the dried oil with a Pt coating was observed and analyzed with an acceleration voltage of $15 \mathrm{kV}$. Many micrococci, bacilli, and filamentous fungi were observed on the surface of the relatively smooth oil (Figure 6). Micrococcus species measure $0.5-2 \mu \mathrm{m}$ in diameter, and bacillus species measure $5-10 \mu \mathrm{m}$ in length and $1-3 \mu \mathrm{m}$ in width. The filamentous fungus species are approximately uniform, measuring 1-2 $\mu \mathrm{m}$ in width, but differ in length widely from several hundred $\mu \mathrm{m}$ to a few $\mu \mathrm{m}$, and branch off and are intertwined (Figure $6 \mathrm{c}$ ). These microorganisms seem to grow up toward the outside from the surface of smooth oil. The elemental content distribution map of the intensive part of the microbe is shown in Figure 7. $\mathrm{Na}, \mathrm{P}, \mathrm{S}, \mathrm{Cl}, \mathrm{Sr}$, and $\mathrm{Pb}$ are distributed conspicuously (Figure 7). In the results of the SEM-EDS half-quantitative analysis, 13 points of the heavy oil analysis are shown in Table 2. The analysis retrieved the values of differences for $\mathrm{Na}(0-16 \%), \mathrm{P}(27-62 \%), \mathrm{S}(4-13 \%)$, $\mathrm{Cl}(0.4-27 \%)$, Fe (2-14\%), Sr (4-7\%), and $\mathrm{Pb}(7-14 \%)$.
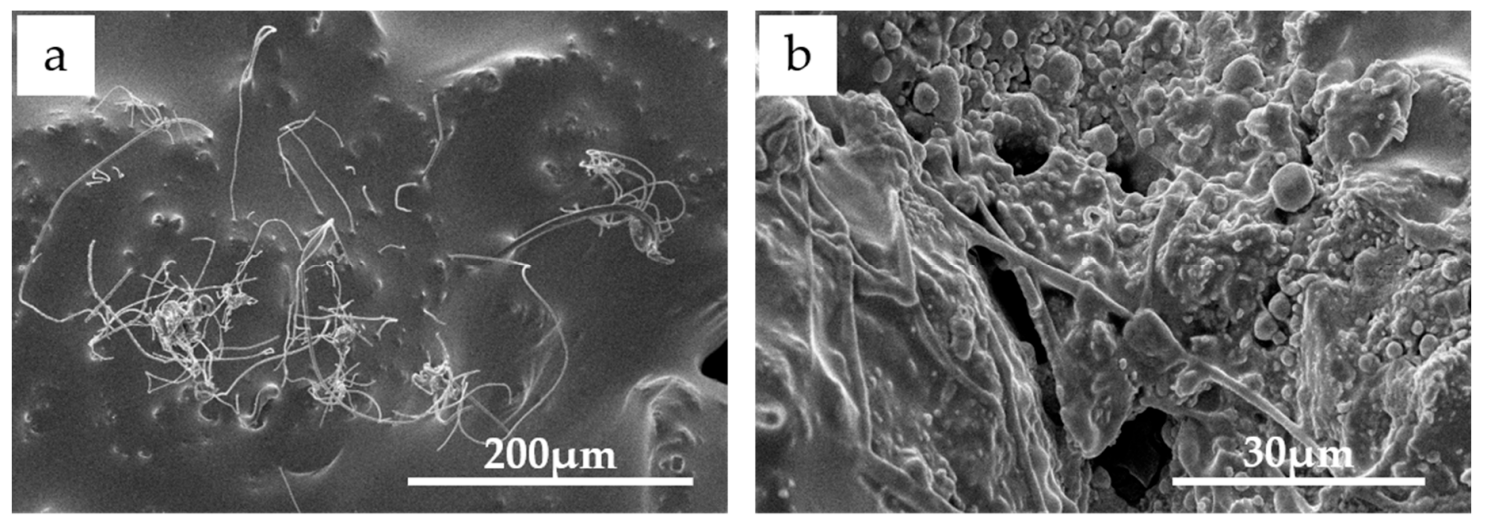

Figure 6. Cont. 

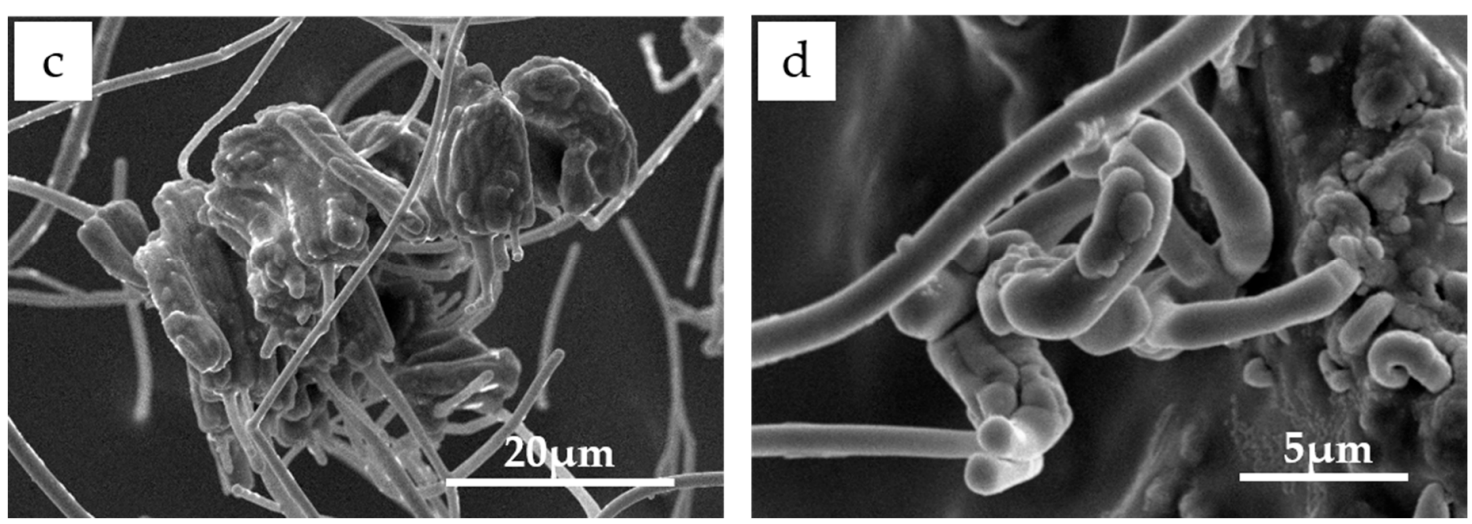

Figure 6. SEM images of the oily polluted soils and rope collected from the Atake seashore in May 2017, showing filamentous microorganisms (a) and coccus-type bacterial colonies (b-d).

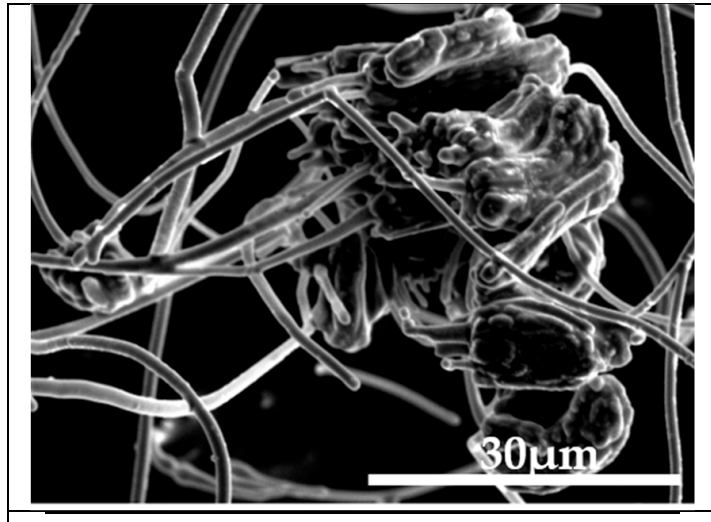

\begin{tabular}{crr}
\hline Elements & Mass \% & \multicolumn{2}{c}{$\begin{array}{c}\text { Atomic } \\
\text { concentration \% }\end{array}$} \\
\hline $\mathrm{Na} \mathrm{K}$ & 6.03 & 15.48 \\
$\mathrm{Mg} \mathrm{K}$ & 0.16 & 0.38 \\
$\mathrm{Si} \mathrm{K}$ & 0.25 & 0.52 \\
$\mathrm{P} \mathrm{K}$ & 19.18 & 36.58 \\
$\mathrm{~S} \mathrm{~K}$ & 2.39 & 4.40 \\
$\mathrm{Cl} \mathrm{K}$ & 16.40 & 27.32 \\
$\mathrm{Ca} \mathrm{K}$ & 0.11 & 0.17 \\
$\mathrm{Fe} \mathrm{K}$ & 1.53 & 1.62 \\
$\mathrm{As} \mathrm{L}$ & 0.69 & 0.54 \\
$\mathrm{Sr} \mathrm{L}$ & 6.34 & 4.27 \\
$\mathrm{~Pb} \mathrm{M}$ & 30.55 & 8.71 \\
\hline
\end{tabular}
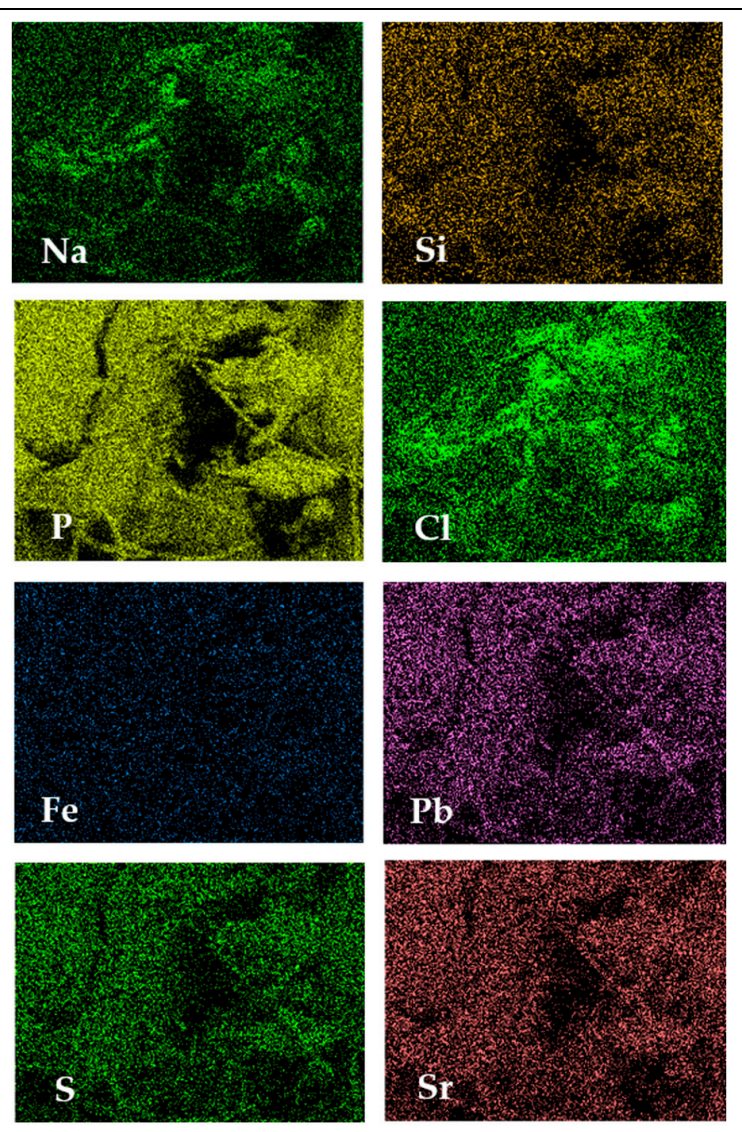

Figure 7. Scanning electron microscopy (SEM) equipped with energy dispersive analyses with an acceleration voltage of $15 \mathrm{kV}$ of the oily soils collected from the Atake seashore on 2 May 2017, indicating a rich presence of $\mathrm{Na}, \mathrm{P}, \mathrm{S}, \mathrm{Cl}, \mathrm{Fe}, \mathrm{Sr}$, and $\mathrm{Pb}$ in the filamentous bacterial colony. 
Table 2. Scanning electron microscopy (SEM) equipped with energy dispersive analyses of oily samples collected from the Atake seashore, showing an abundance of $\mathrm{Na}, \mathrm{Si}, \mathrm{P}, \mathrm{S}, \mathrm{Cl}, \mathrm{Fe}$, Sr, and Pb (EDS system; Pt coating samples; acc. vol. $15 \mathrm{kV}$ ).

\begin{tabular}{|c|c|c|c|c|c|c|c|c|c|c|c|c|c|}
\hline Elements & Point 1 & Point 2 & Point 3 & Point 4 & Point 5 & Point 6 & Point 7 & Point 8 & Point 9 & Point 10 & Point 11 & Point 12 & Point 13 \\
\hline $\mathrm{Na} K$ & 15.48 & 12.96 & 15.82 & 2.69 & 11.98 & 6.69 & 7.77 & 9.94 & 1.38 & 1.83 & 0.88 & 0.52 & 0.00 \\
\hline $\mathrm{Mg} \mathrm{K}$ & 0.38 & 0.38 & 0.00 & 2.58 & 0.57 & 1.53 & 1.24 & 1.01 & 0.91 & 0.46 & 0.38 & 0.93 & 0.41 \\
\hline Si K & 0.52 & 1.30 & 4.03 & 8.68 & 6.45 & 14.35 & 15.09 & 6.90 & 14.33 & 18.50 & 1.25 & 0.00 & 0.10 \\
\hline PK & 36.58 & 41.45 & 26.81 & 43.92 & 35.17 & 38.31 & 36.49 & 38.32 & 47.81 & 46.06 & 57.92 & 58.47 & 62.16 \\
\hline S K & 4.40 & 4.96 & 6.49 & 5.33 & 4.87 & 4.87 & 4.95 & 5.34 & 8.96 & 6.87 & 11.87 & 12.75 & 11.24 \\
\hline $\mathrm{Cl} \mathrm{K}$ & 27.32 & 20.30 & 20.50 & 7.82 & 20.48 & 13.29 & 14.49 & 16.91 & 1.90 & 0.43 & 2.07 & 2.01 & 1.09 \\
\hline K K & 0.00 & 0.34 & 0.24 & 0.30 & 0.24 & 0.13 & 0.32 & 0.36 & 0.80 & 2.18 & 0.00 & 0.36 & 0.00 \\
\hline Ca K & 0.17 & 0.02 & 0.39 & 1.20 & 0.33 & 0.85 & 0.90 & 0.59 & 0.48 & 1.69 & 0.21 & 0.26 & 0.06 \\
\hline Mn K & 0.00 & 0.27 & 0.13 & 0.54 & 0.02 & 0.00 & 0.00 & 0.14 & 0.00 & 0.00 & 0.22 & 0.29 & 0.00 \\
\hline Fe K & 1.62 & 2.30 & 13.74 & 10.45 & 5.49 & 4.56 & 3.62 & 5.44 & 4.45 & 4.16 & 3.14 & 2.13 & 2.72 \\
\hline $\mathrm{Cu} \mathrm{L}$ & 0.00 & 0.24 & 0.14 & 0.55 & 0.28 & 0.00 & 0.08 & 0.11 & 0.41 & 0.21 & 0.43 & 0.66 & 0.06 \\
\hline As L & 0.54 & 0.72 & 0.63 & 0.51 & 0.42 & 0.37 & 0.60 & 0.69 & 0.72 & 0.73 & 1.03 & 0.98 & 1.04 \\
\hline Sr L & 4.27 & 5.24 & 3.99 & 6.18 & 5.09 & 6.24 & 6.03 & 5.50 & 7.37 & 7.37 & 7.12 & 7.03 & 7.38 \\
\hline $\mathrm{Pb} \mathrm{M}$ & 8.71 & 9.51 & 7.12 & 9.24 & 8.63 & 8.60 & 8.41 & 8.75 & 10.48 & 9.50 & 13.48 & 13.60 & 13.74 \\
\hline Total & 99.99 & 99.99 & 100.03 & 99.99 & 100.02 & 99.79 & 99.99 & 100.00 & 100.00 & 99.99 & 100.00 & 99.99 & 100.00 \\
\hline
\end{tabular}




\section{Discussion}

We studied the microstructure, mineralogy, chemical composition, and radioactivity associated with microorganisms in the soils, and buried fishing nets and ropes that were contaminated with C-type heavy oil from the Nakhodka tanker in 1997. We observed the oil-contaminated soils on the rope at the Atake seashore, which indicated paraffin wax, graphite, sulfur, calcite, and halite associated with many microorganisms in 2017, after 20 years, suggesting that microbial activity may play a significant role in the nucleation of clays, and that this may be a common occurrence. In the case of oxidic conditions under sunshine with high ultraviolet rays, oily surfaces of rocks produced graphite, calcite, and crystalline paraffin wax associated with coccus, bacillus, pseudomonas, and alkane-degrading bacteria from 2001-2017. The 20 years after the accident, graphite, calcite, clay minerals, and paraffin wax were produced associated with hydrocarbon-degrading bacteria. The results of XRD and SEM-EDS support this observation, as shown in Figure 8.

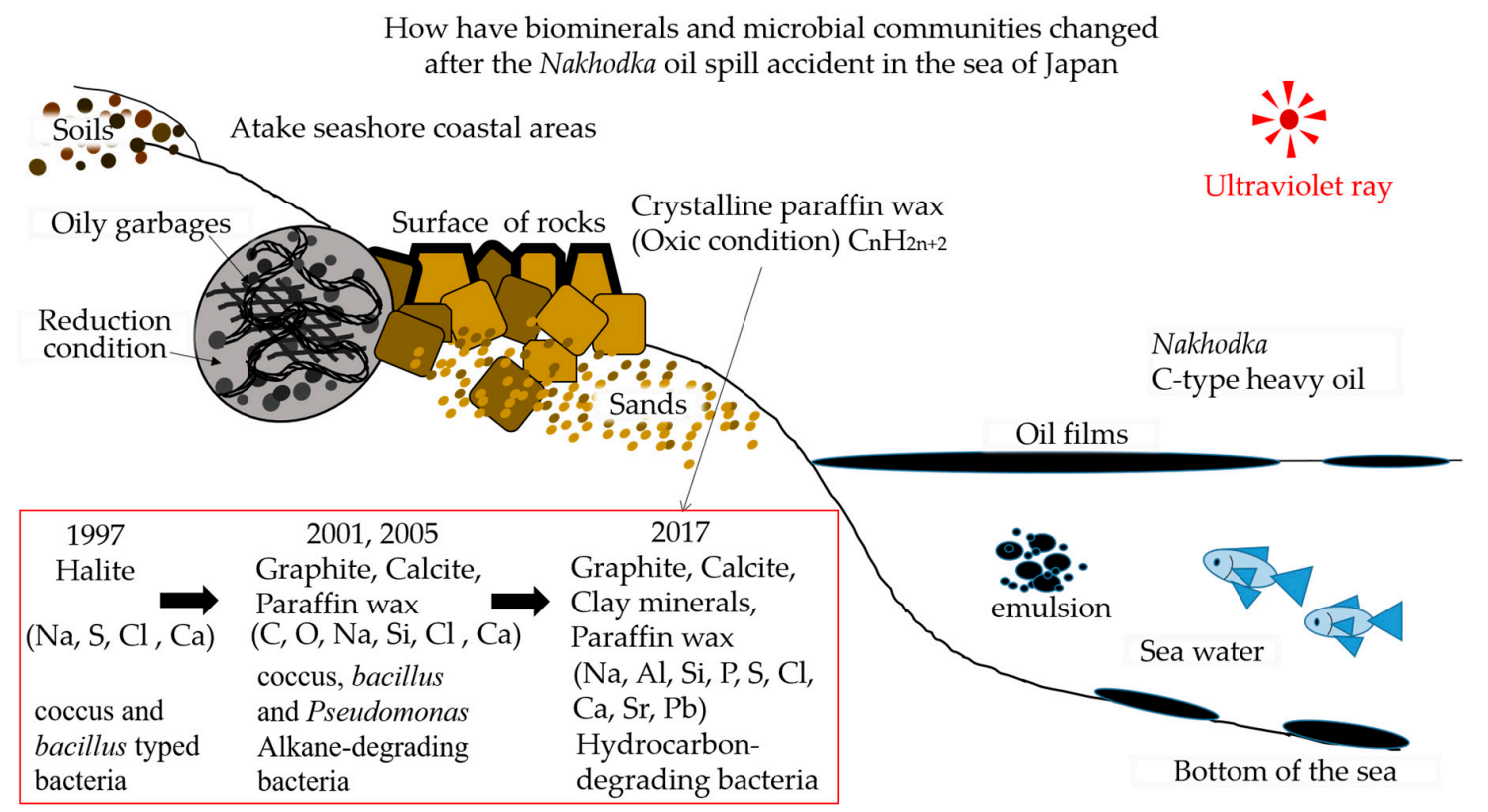

Figure 8. Illustrated schema of "How have contamination changed from 1997 to 2017", 20 years after the Nakhodka heavy oil spill accident. The schematic diagram illustrates one possible mechanism of heavy oil contamination, depending on the oxidation or reduction conditions.

Various kinds of microorganisms associated with oil, such as Methanococci, Archaeoglobi, Phylum Thaumarchaeota, Geoglobus ahangari, and Archaeoglobus fulgidus have been found [1-10]. Several of our previous works have articulated the data obtained in the present results. A schematic illustrating one possible mechanism of heavy oil bioremediation is shown in Figure 8.

We have reported on the bioremediation of coastal areas from 1997 to 2017 after the Nakhodka oil spill accident, such as the characterization of hydrocarbon-degrading bacteria, alkane-degrading bacteria, interactions between clay minerals and hydrocarbon-utilizing indigenous microorganisms, paraffin formation by hydrocarbon-degrading bacteria, bacterial mineralization, and the bioavailability of kaolinite. This is possible because the microorganisms in the heavy oil and soils produces oxalic acids and many other acids and enzymes, pockmarking rock and sequestering calcium and other minerals to form calcium oxalates [1,6,8-14].

\subsection{After Nine Years of Bioremediation at the Seashore}

The impact of the Nakhodka oil spill resulted in a viscous sticky fluid fouling the shores and affecting natural ecosystems. Weathering by hydrocarbon-degrading bacteria (genus Pseudomonas) and 
crystallized organic compounds were observed from the oil spill-polluted seashores after nine years. XRD analyses of hardened and formed crusts on the surface of rocks near the seashore indicated the presence of crystalline wax $(0.422 \mathrm{~nm}, 0.377 \mathrm{~nm}$, and $0.250 \mathrm{~nm}$ d-spacing $)$ in association with graphite and calcite after nine years of bioremediation. The anaerobic reverse side of the oil crust contained numerous coccus-type bacteria associated with halite. The finding of hydrocarbon-degrading bacteria and paraffin wax in the oil crust suggests that they may have had a significant effect on the weathering processes of the Nakhodka oil spill during the nine-year bioremediation [8,9]. It is likely that the clay bubbles on the surface of bacterial cells are the bioorganic product of bacterial gassing or vesicle formation activity. Halloysite-like mineral formation in soils may be substantially enhanced by the presence of bacteria $[15,16]$.

Upon the slow evaporation of the Nakhodka oil spill during the nine-year weathering, the dendritic crystal growth of paraffin (a mixture of alkanes) occurred in the oil crust under natural conditions (Figure 1d). The XRD studies suggest that the ridges formed in certain crystallographic directions on the crystals of normal alkanes were related to the shearing which occurs when molecular chains undergo tilting. Heavy metals were obtained in the original heavy oil samples of three seashores in the Sea of Japan, indicating that $\mathrm{Si}, \mathrm{S}, \mathrm{Ti}, \mathrm{Cr}, \mathrm{Ni}, \mathrm{Cu}$, and $\mathrm{Zn}$ were predominantly indigenous to the Nakhodka oil spill, whereas these heavy metals and $\mathrm{S}$ were not found in the crust after nine years of weathering (Figure 4h-k) [11,17-20]. In addition, we need to conduct FT-IR analysis for the samples in our future study.

\subsection{Rock Was Covered with Hardened Oil Crusts}

The sample that was kept for 20 years in a box is shown in Figure $1 \mathrm{~d}$. The rock surface contaminated by the Nakhodka oil spill at the Mikuni seashore in the Sea of Japan had weathered in the nine intervening years when collected at Anto, Mikuni seashore, Sakai (Mikuni), Fukui on 25 October 2005. The surface was covered with hardened oil crusts. The surface was black, but it was not sticky, had no oily odor, and had a dry surface (Figure $4 \mathrm{~h}-\mathrm{i}$ ). The result of analyses by XRD, ED-XRF, SEM-EDS, and TEM with the same sample nine years after the oil spill confirmed that the surface heavy oil had changed to paraffin wax. The analyses of the C-type heavy oil at the time of the Nakhodka oil spill accident are shown in the Appendix A [1,2,6].

\subsection{The Resolution of Heavy Oils into Substances and Biomineralization Processes, 1997-2005}

(1) Several types of microorganisms were observed in the heavy oil-predominantly abundant bacteria such as coccus, bacillus, and spirillum. The oil-degrading bacterial groups or bacteria are distributed in the seashore around the Noto Peninsula. The SEM observation found the microorganisms adhering to the oil particles. The EDS spectrum of microorganisms showed a significant peak of $S$ associated with $\mathrm{Al}, \mathrm{Si}, \mathrm{Cl}$, and $\mathrm{Ca}$ (Appendix A Tables A1-A6) [1,2,8,9].

(2) The rocks covered by oil lay at the beach and seashore without any treatments.

In 1997-(Figure 4a,b): coccus and bacilli around oil drops sticking together are associated with square salt grains of halite. (Figure 4c,d); SEM-EDS of earthworm typed bacteria, 5-10 $\mu \mathrm{m}$ long, intertwine, which are composed of a high background of organic carbon associated with high concentrations of $\mathrm{S}, \mathrm{Cl}$, and $\mathrm{Ca}$.

In 2001-(Figure 4e-g): a variety of morphological forms of bacteria, such as coccus, bacillus, and pseudomonas. Alkane-degrading bacteria can be seen in oil that was pulled out from the Nakhodka tanker. (f) bacilli at the Katano seashore (Figure 1a). (g) cocci at the Osawa seaside five years after the accident (Figure 1a).

In 2005-(Figure 4h-k); The heavy oil flattened itself against the rock's surface at the Mikuni coast after nine years from a heavy oil spilled accident (h). The black oil had transformed into paraffin wax films, which came off the rock surface easily (i), and cocci can be seen by SEM (j), whereas thin films covering the cocci can be seen by TEM $(\mathrm{k})$. 
This accident has been the catalyst for remarkable advances in microbial remediation research. We were permitted to describe what was happening throughout the Hokuriku District for 20 years. In fact, hydrocarbon-degrading microbes were found in each polluted area of the near-shore environments. Microbial degradation of petroleum is of considerable environmental importance, where microbial degradation is the conversion process that dissolves and disperses hydrocarbons into oxidized products by microorganisms $[1,2,8]$.

(3) Heavy oils and organic materials which decomposed in the soils by microorganisms.

(4) Heavy oils on the surface of seaside rocks dried up, changing to paraffin $\left(\mathrm{C}_{n} \mathrm{H}_{2 n+2}\right)$ and graphite, sequestering $\mathrm{O}_{2}+\mathrm{CO}_{2}$ from the sun's ultraviolet radiation.

\section{Summary}

(1) Various kinds of bacteria in heavy oils have propagated in the soils near the coast of the Atake seashore, Wajima, Ishikawa, Japan.

(2) Paraffin $\left(\mathrm{C}_{n} \mathrm{H}_{2 n+2}\right)$ wax, graphite, and calcite have been developed on the dried surfaces of rocks with ultraviolet rays at the seaside.

(3) The XRD analyses of oily soils and rope at the Atake seashore, 20 years after the Nakhodka oil spill accident, revealed 14 A clays, biotite, paraffin wax, cristobalite, sulfur, graphite, halite, and calcite (Figure 3), which have a role as adsorbents and microbial growth-support media in enhancing the degradation of crude oil at the Atake seashore.

A schematic diagram illustrating one possible mechanism of the biodegradation processes of the Nakhodka oil spill during the 20-year bioremediation from 1997 to 2017, in Ishikawa, Japan, showing different conditions between oxidic conditions under the sun and reduction conditions in the soils at the seaside. The crystalline paraffin wax $\left(\mathrm{C}_{n} \mathrm{H}_{2 n+2}\right)$ at oxidic conditions had been developed on the surface of rocks beyond the seaside. The clays, biotite, paraffin wax, cristobalite, graphite, calcite, and halite were developed in the soils of the seaside over 20 years.

The degradation of crude oil apparently resulted from a favorable synergism between clay minerals and hydrocarbon-degrading microorganisms. The ubiquitous presence of microorganisms in crude oil and introduced clays indicated that clays were not a limiting factor for the growth of microorganisms in degrading crude oil. Instead, the presence of the clays resulted in the growth of microorganisms that produced polysaccharides, which brought about biofilm formation that accelerated the degradation of crude oil. The clay minerals had roles as adsorbents and microbial growth-support media in enhancing the degradation of crude oil.

Our present data also provide significant insight into how these metals in the Nakhodka oil spill affected the biodegradation of heavy oil during the 20-year bioremediation, thereby giving more fruitful information for such kinds of oil spills. In contrast, these results also provided information that the Nakhodka oil spill resulted in not only hydrocarbons, but also heavy metal pollutants, along the coastal area of the Sea of Japan.

\section{Conclusions}

Twenty years after the 1997 Nakhodka oil spill accident in the Sea of Japan, several kinds of microorganisms were found in the heavy oil from the Atake seashore in January 2017, suggesting bioremediation processes. We studied the microstructure, mineralogy, chemical composition, and radioactivity associated with microorganisms in the contaminated soils with C-type heavy oil with fishing nets and ropes, using a combination of micro techniques, analytical data based on a CHN analyzer, XRD, and scanning electron microscopy equipped with energy distribution spectroscopy (SEM-EDS). Hydrocarbon-degrading bacteria, paraffin, and graphite were present on the Nakhodka oil spill-polluted seashores after 20 years in the soils, indicating that high concentrations of $\mathrm{Na}, \mathrm{P}, \mathrm{S}, \mathrm{Cl}, \mathrm{Sr}$, and $\mathrm{Pb}$ were predominantly linked to the Nakhodka oil spill.

The XRD data suggest that the minerals and clay minerals may facilitate hydrocarbon-degrading bacterial growth, as shown in our previous study. The finding of hydrocarbon-degrading bacteria, 
graphite, and paraffin wax in the oily soils may have had a significant effect on the weathering processes of the Nakhodka oil spill during the 20-year bioremediation process. The microorganisms are nature's grand molecular disassemblers of the oil, soil, and seawater, and are very fast in their growth. We have used SEM-EDS for 20 years, showing semi-permanent bioremediation processes. The mineral formation in the oily contaminated soils may be substantially enhanced by the presence of microorganisms. This has significant implications for the ecological concept of remediation.

Author Contributions: K.T. and A.F. conceived and designed the paper; K.T., A.F., F.T., Y.S., M.S., Y.K., K.S., and K.K. designed the field work and sampling; K.T., K.N., and T.T. performed the XRD and SEM-EDS; K.T., A.F., and F.T. interpreted the data and wrote the manuscript; and K.T., A.F., and F.T. designed the figures and tables.

Acknowledgments: We are grateful for the support from Wakura Co. (Yusuke Katayama). The authors also wish to thank Hirono Tazaki, Mutsumi Shintaku, Kazuya Katayama, and Naruhito Koshizaki in TV Kanazawa for kind support in this research. The authors would also like to thank Enago (www.enago.jp) for the English language review. We would like to express our appreciation to the three anonymous reviewers for their distinguished comments.

Conflicts of Interest: The authors declare no conflicts of interest.

\section{Appendix A. The Chemical Composition of Heavy Oil Spilled from the Nakhodka Oil Tanker in} 1997-2003

Table A1. Elemental composition of sea water by ED-XRF $[13,14]$.

\begin{tabular}{cc}
\hline Element & wt \% \\
\hline $\mathrm{Na}$ & 8.27 \\
$\mathrm{Mg}$ & 1.49 \\
$\mathrm{Si}$ & 0.26 \\
$\mathrm{~S}$ & 2.94 \\
$\mathrm{Cl}$ & 79.94 \\
$\mathrm{~K}$ & 2.99 \\
$\mathrm{Ca}$ & 3.57 \\
$\mathrm{Co}$ & 0.05 \\
$\mathrm{Br}$ & 0.42 \\
$\mathrm{Sr}$ & 0.06 \\
\hline
\end{tabular}

Table A2. Average elemental composition (wt \%) of beach sands collected from Katano seashore and Atake seashore analyzed by ED-XRF.

\begin{tabular}{ccc}
\hline Element & Katano (1999/12/10) $(\mathbf{y y} / \mathbf{m m} / \mathbf{d d})$ & Atake $(\mathbf{2 0 0 3 / 1 1 / 2 1 )}(\mathbf{y y} / \mathbf{m m} / \mathbf{d d})$ \\
\hline $\mathrm{Mg}$ & 0.34 & 0.55 \\
$\mathrm{Al}$ & 6.55 & 9.62 \\
$\mathrm{Si}$ & 73.16 & 59.19 \\
$\mathrm{~K}$ & 8.77 & 11.42 \\
$\mathrm{Ca}$ & 2.45 & 7.00 \\
$\mathrm{Ti}$ & 0.77 & 1.27 \\
$\mathrm{Mn}$ & 0.15 & 0.13 \\
$\mathrm{Fe}$ & 7.73 & 10.61 \\
$\mathrm{Sr}$ & 0.07 & 0.21 \\
\hline
\end{tabular}

Samples of beach sands were collected from Katano seashore on 10 December 1999, and from Atake seashore on 21 November 2003. The beach sand is mainly composed of quartz $\left(\mathrm{SiO}_{2}\right)$, feldspars ( $\left.\mathrm{Al}-\mathrm{Si}\right)$ and very few clay minerals [13]. 
Table A3. The initial composition of heavy oil spilled from the Nakhodka oil tanker anlyzed by CHNS chemical analyzer (FISONS) (wt \%) [3].

\begin{tabular}{ccccccccc}
\hline $\begin{array}{c}\text { Chemical Composition of Heavy Oil. } \\
\text { The Samples Were Anlyzed in 1997 }\end{array}$ & $\begin{array}{c}\text { Nakhodka } \\
\mathbf{/ 2 / 6}\end{array}$ & $\begin{array}{c}\text { Mikuni } \\
\mathbf{/ 1 / 9}\end{array}$ & $\begin{array}{c}\text { Kaga } \\
\mathbf{/ 1 / 1 0}\end{array}$ & $\begin{array}{c}\text { Togi } \\
\mathbf{/ 1 / 1 7}\end{array}$ & $\begin{array}{c}\text { Suzu } \\
\mathbf{/ 1 / 1 8}\end{array}$ & $\begin{array}{c}\text { Osawa } \\
\mathbf{/ 1 / 2 7}\end{array}$ & $\begin{array}{c}\text { Togi a } \\
\mathbf{/ 9 / 1 9}\end{array}$ & $\begin{array}{c}\text { Togi } \mathbf{~} \\
\mathbf{1 9 / 1 9}\end{array}$ \\
\hline Carbon & 62.2 & 41.2 & 8.41 & 65.7 & 38.8 & 35.8 & 38.0 & 27.6 \\
Hydrogen & 10.1 & 10.1 & 1.2 & 9.9 & 10.4 & 10.1 & 6.8 & 2.7 \\
Nitrogen & 0.246 & 0.196 & 0.114 & 0.341 & 0.19 & 0.214 & 1.152 & 1.183 \\
Sulfur & $<0.1$ & 0.29 & 0.15 & 0.89 & 0.07 & 0.14 & 0.32 & $<0.1$ \\
Oxygen & 27.4 & 48.2 & 90.2 & 23.2 & 50.5 & 53.7 & 53.7 & 68.5 \\
\hline
\end{tabular}

Table A4. Physical characteristics of seawater at Atake seashore. These parameters were measured in November 2001 [13].

\begin{tabular}{|c|c|c|c|c|c|c|c|c|c|}
\hline $\begin{array}{l}\text { Sampling Site } \\
\text { Atake Seashore }\end{array}$ & $\begin{array}{c}\text { Sample Source } \\
\text { (yy/mm/dd) }\end{array}$ & pH & $\begin{array}{c}\text { Eh } \\
(\mathrm{mV})\end{array}$ & $\begin{array}{c}\mathrm{EC} \\
(\mathrm{mS} / \mathrm{cm})\end{array}$ & $\begin{array}{c}\mathrm{DO} \\
(\mathrm{mS} / \mathrm{L})\end{array}$ & $\begin{array}{l}\text { WT } \\
\left({ }^{\circ} \mathrm{C}\right)\end{array}$ & $\begin{array}{c}\mathrm{N} \\
(w \mathrm{t} \%)\end{array}$ & $\begin{array}{c}\mathrm{C} \\
\text { (wt \%) }\end{array}$ & $\begin{array}{c}S \\
(w t \%)\end{array}$ \\
\hline seawater & $1997 / 7 / 26$ & 8.4 & 100 & 44 & 10.9 & 28.0 & & & \\
\hline seawater + heavy oil & $1997 / 11 / 6$ & 8.5 & 210 & 41 & 2.6 & 13.1 & & & \\
\hline seawater & $2001 / 11 / 6$ & 8.6 & 75 & 48.6 & 9.6 & 16.5 & n.d. & 0.03 & 2.27 \\
\hline seawater + heavy oil & $2001 / 11 / 6$ & 8.3 & 118 & 19 & 4.8 & 14 & n.d. & 0.1 & 2.44 \\
\hline \multicolumn{7}{|c|}{ Nakhodka tanker (seawater + havy oil) } & n.d. & 87.2 & 1.44 \\
\hline \multicolumn{7}{|c|}{ heavy oil (outside seashore) } & n.d. & 83.4 & 1.38 \\
\hline \multicolumn{7}{|c|}{ heavy oil (near shore) } & 0.22 & 82.9 & 1.20 \\
\hline
\end{tabular}

N: nitorogen; C: carbon; S: sulfur; n.d.: not detected.

Table A5. Ash, acid insoluble, and inorganic components in the oil drawn from Nakhodka's cargo tanks [21].

\begin{tabular}{|c|c|c|c|c|c|c|c|c|c|c|c|c|c|}
\hline \multirow{2}{*}{$\begin{array}{l}\text { Ash } \\
(\%)\end{array}$} & \multirow{2}{*}{$\begin{array}{c}\text { Insolubles } \\
(\%)\end{array}$} & \multicolumn{12}{|c|}{ Elements (ppm) (Mean Value from Three Replicates) } \\
\hline & & $\mathrm{Mg}$ & Al & Si & $\mathbf{V}$ & $\mathrm{Cr}$ & Mn & $\mathrm{Fe}$ & $\mathrm{Ni}$ & $\mathrm{Cu}$ & As & $\mathrm{Cd}$ & $\mathbf{P b}$ \\
\hline 1.30 & 0.10 & 786 & $123-138$ & 254 & 8.2 & 7.8 & 0.24 & 185 & 5.2 & 0.67 & 20 & 0.74 & 0.27 \\
\hline
\end{tabular}

Table A6. Volatile aromatic hydrocarbon concentrations in heavy fuel oil from the Nakhodoka tanker [22].

\begin{tabular}{ccc}
\hline Chemical & Boiling Point $\left({ }^{\circ} \mathbf{C}\right)$ & Concentration $\left(\mu \mathrm{g} \cdot \mathbf{g}^{-\mathbf{1}}\right)$ \\
\hline Benzene & 80.1 & 8.8 \\
Toluene & 110.6 & 120 \\
$m$ - and $p$-Xylene & $139.3(m-), 137-138(p-)$ & 43 \\
$o-X y l e n e$ & 144 & 88 \\
Naphthalene & 218 & 408 \\
Fluorene & 295 & 126 \\
\hline
\end{tabular}

\section{References}

1. Tazaki, K. Heavy Oil Spilled from Russian Tanker "Nakhodka" in 1997: Towards Eco-Responsibility, Earth Sense; 21st Century COE Kanazawa University Long- and Short-Term Dynamics of Pan-Japan Sea Area; Environmental Monitoring and Prediction Program; The 21st Century COE Program of Kanazawa University: Kanazawa, Japan, 2003; p. 440.

2. Tazaki, K. Water and soil Environments; Biological and Geological Perspectives. In Proceedings of the International Symposium of the Kanazawa University 21st-Century COE Program, Kanazawa, Japan, 7-18 March 2003; p. 401.

3. Sampei, Y.; Tazaki, K.; Obata, Y.; Yoshimura, T.; Sawano, N.; Takayasu, K.; Iizumi, S.; Tokuoka, T. Compositional changes of heavy oil and aliphatic hydrocarbon from the spilled Nakhodka oil washed ashore at Fukui, Ishikawa and Niigata Prefectures, Japan. In Heavy Oil Spilled from Russian Tanker "Nakhodka" in 1997: Towards Eco-Responsibility, Earth Sense; Tazaki, K., Ed.; The 21st Century COE Program of Kanazawa University: Kanazawa, Japan, 2003; pp. 37-38, 174-191. 
4. Tazaki, K. Russian Tanker "Nakhodka" oil spill accident in 1997. Sci. Viewp. Corresp. Jpn. Sci. 1998, 38 , 43-47.

5. Tazaki, K. Bacterial activity at the global environment. Geol. Collect. Essays 1998, 49, 137-147.

6. Tazaki, K. Microorganisms design Earth history. In Proceedings of the International Symposium “Earth-Water-Humans", Kanazawa, Japan, 30 May-1 June 1999; pp. 187-196.

7. Tazaki, K.; Hayakawa, K. Heavy Oil Spilled from Russian Tanker "Nakhodka" in 1997: Towards Eco-Responsibility, Earth Sense; The 21st Century COE Program of Kanazawa University: Kanazawa, Japan, 2006; p. 98.

8. Tazaki, K.; Watanabe, H.; Chaerun, S.K.; Shiraki, K.; Asada, R. Hydrocarbon-Degrading Bacteria and Paraffin from Polluted Seashores 9 Years after the Nakhodka Oil Spill in the Sea of Japan. Acta Geol. Sin. 2006, 80, 432-440. [CrossRef]

9. Tazaki, K.; Fukuyama, A.; Tazaki, F.; Shintaku, Y.; Shintaku, M.; Katayama, K.; Nakamura, K.; Takehara, T.; Katsura, Y.; Shimada, K. 20 years after the Nakhodka oil spill accident in the Sea of Japan. In Proceedings of the 27th Symposium on Geo-Environments and Geo-Technics, Tokyo, Japan, 1-2 December 2017; pp. 97-104.

10. Tazaki, K.; Chaerun, S.K. Life in oil: Hydrocarbon-degrading bacterial mineralization in oil spill-polluted marine environment. Front. Mater. Sci. China 2008, 2, 120-133. [CrossRef]

11. Tazaki, K. Oil Spill Off the Taean Peninsula, South Korea, on December 7th, 2007-Surveys One Month, Ten Months, and One Year after the Accident. Sci. Rep. Kanazawa Univ. 2009, 52, 1-23.

12. Chaerun, S.K.; Tazaki, K. Effect of kaolinite on microbial growth in high concentration of heavy oil. Clay Sci. 2003, 12, 187-196.

13. Chaerun, S.K.; Tazaki, K.; Asada, R.; Kogure, K. Biodegradation of coastal area 5 years after the Nakhodoka oil spill in the Sea of Japan: Isolation and characterization of hydrocarbon-degrading bacteria. Environ. Int. 2004, 30, 911-922. [CrossRef] [PubMed]

14. Chaerun, S.K.; Tazaki, K.; Asada, R.; Kogure, K. Alkane-Degrading Bacteria and Heavy Metals from the Nakhodka Oil Spill-Polluted Seashores in the Sea of Japan after Five Years of Bioremediation. Sci. Rep. Kanazawa Univ. 2005, 49, 25-46.

15. Tazaki, K.; Fyfe, W.S. Primitive clay precursors formed on feldspar. Can. J. Earth Sci. 1987, 24, 506-527. [CrossRef]

16. Nelson-Smith, A. Oil Pollution and Marine Ecology; Elek Science: London, UK, 1972; p. 260.

17. Chaerun, S.K.; Tazaki, K.; Asada, R.; Kogure, K. Interaction between clay minerals and hydrocarbon-utilizing indigenous microorganisms in high concentrations of heavy oil: Implications for bioremediation. Clay Miner. 2005, 40, 105-114. [CrossRef]

18. Chaerun, S.K.; Tazaki, K. How kaolinite plays an essential role in remediating oil-polluted seawater. Clay Miner. 2005, 40, 481-491. [CrossRef]

19. Chaerun, S.K.; Asada, R.; Tazaki, K. Biodegradation of heavy oil from the Nakhodoka oil spill by indigenous microbial consortia. Int. J. Appl. Environ. Sci. 2007, 2, 19-30.

20. Tazaki, K. Microbial formation of halloysite-like mineral. Clays Clay Miner. 2005, 53, 224-233. [CrossRef]

21. Matsumoto, K. Determination of water, ash, and inorganic components in heavy fuel oil drawn from the Nakhodka's cargo tanks. In Heavy Oil Spilled from Russian Tanker "Nakhodka" in 1997: Towards Eco-Responsibility, Earth Sense; Tazaki, K., Ed.; The 21st Century COE Program of Kanazawa University: Kanazawa, Japan, 2006; pp. 203-213.

22. Murahashi, T.; Kizu, R.; Hayakawa, K. Volatile aromatic hydrocarbon concentrations in heavy fuel oil and the atmosphere collected from seashores affected by an oil spill. In Heavy Oil Spilled from Russian Tanker "Nakhodka" in 1997: Towards Eco-Responsibility, Earth Sense; Tazaki, K., Ed.; The 21st Century COE Program of Kanazawa University: Kanazawa, Japan, 2006; pp. 231-239.

(C) 2018 by the authors. Licensee MDPI, Basel, Switzerland. This article is an open access article distributed under the terms and conditions of the Creative Commons Attribution (CC BY) license (http:// creativecommons.org/licenses/by/4.0/). 